\title{
ROLE OF FAIR TRADE AND ITS STRATEGIC IMPLICATIONS TO ORGANIZATION DECISION MAKING
}

\author{
Sunday C. Eze and Adenike O. Bello \\ Department of Business Studies, Landmark University Omu-Aran Kwara State, Nigeria
}

\begin{abstract}
Fair-trade is concerned with ensuring that producers are paid fair wages and that fair prices are charged consumers in a bid to promote equitable trading agreement (shaw et al 2006). This paper investigates recent discourse associated with fair trade particularly clothing companies. It argues for fair trade as a veritable tool for ensuring fair wages and prices but points out some of the issues concerned with carrying out fair trade activities. This paper was based on secondary data. The findings suggest that despite the relevant roles fair trade plays, and the high media publicity associated with it, most consumers still find it difficult to recognise fair trade products because of the negative practices and poor promotional efforts with companies. While this paper highlights some of the unethical practices organisations have engaged which impact negatively on fair trade, it suggests some of the remedies especially to organisations that have interest in practicing fair trade in future. The study recommendations that providing certified labelling will enable consumers read and identify fair trade product easily. It also recommends that ensuring adequate corporate social responsibility and quality of the products are way forward.
\end{abstract}

\section{KEYWORDS: Discourse, Fair Trade, Clothing Companies}

\section{INTRODUCTION}

Advances in Information Communication Technology (ICT) has reduced the influence/ impact distance has on consumers. This has made consumers more familiar with products /services in different countries or regions and led to understanding of the social and ethical concerns globally. Retailers have followed this trend more regularly and have adopted positioning strategies to adapt to this trend (Nijssen and Dogulas 2008). Through the internet, consumers no longer limit their search for products in one particular region. Consumers also travel wide and near which expose them to different cultures, norms, lifestyles in different countries leading to openness, adaptability and zeal to try now experiences. These experiences have important implication to increased awareness especially in most developing countries where most raw materials are being extracted and transported to western world. Awareness of information through the use of ICT especially in developing countries has made these less privileged countries familiar with global issues such as human rights, fair trade and ecological problems. This motivates consumers to buy products bearing ethical issues in mind (Nijssen and Dogulas 2008). Nijsigsen and Dogulas (2008) point out that ethical practices have increased with regards to number of outlet, and help to store environmental friendly products leading to support of fair trade by retailers such as Wal-Mart and Gap in western countries.

The rise in awareness of consumers and producers have an influence on their consumption pattern which has led to massive increase in demand for more alternative products produced and sold based on ethical considerations. However, despite the increase in consumers' awareness and concerns and the high media attention, fair trade has been argued to be ultimately, the only way out for sustainable development (Anita, 1994). Nadia (2007) reports 
that a survey conducted by a company called Fair Indigo found that 86 percent of consumers care about products and cloths they buy. He further noted that just few years ago most countries like UK and America have never indulge in fair trade, but today organisations like the McDonald's and Wal-Mart have engaged in fair-trade and use this means to source for raw materials they use and in turn pay wages. The massive growth in sales of fair trade products have been one of the most widely recognized evidences, though it has been observed that only few buyers of fair trade products pander on ethical principle when dealing with fair trade products (Nicolas and Lee 2006). Therefore, this paper examines the role of fair trade in organizations with emphasis on fashion/clothing, and its strategic implications to organizational decision making. This paper is structured as follows. First, it looks at the meaning of fair trade, analyses and discusses issues associated with fair trade and finally conclusion and recommendation.

\section{LITERATURE REVIEW}

\section{What is Fair Trade?}

Although there is no yard stick to measure what is fair, however, fair trade is concerned with a wage that will enable labours to live relatively comfortable in their countries (Nadia, 2007). In a more holistic manner, Becchetti and Rosati (2007) point out that fair trade products have a series of social and environmental criteria that must be adhered to. Firstly, fair trade represents a higher price than the market price on primary products. Adopting this criteria means that the marketing principals are not violated in the sense that buyers who buy these products are highly concentrated. These buyers use their market influence to buy products at a certain price which are below the value charged by primary producers' (b) Fair trade products are more of conditional products and cannot be compared with those of traditional products thereby lowering incompetence and improving the standard of living of consumers. (c) It helps in financing production even before the production takes place thus, breaks the monopoly of money lenders that have advice effects on small producers. (d) It helps in stability by reducing the risk of high price of products. (e) It is a way to improve the lives and working conditions and avoid those factors that triggered child labour. (f) It triggers efforts to plough back some of the profits arising from the fair price form the local goods. (g) Environmental sustainability. (h) Price determination and finally the building of long term relationships between the producers and the buyers in various countries (Becchetti and Rosati, 2007).

Fair trade has become an alternative market approach that ensures that wellbeing of small producers particularly in developing countries are maintained (Obermiller et al., 2009).The concept of fair trade is concerned with ensuring that fair price and fair working condition for producers and suppliers through equitable trading agreement or regulations. According to Anita (1994), it simply means avoiding direct exploitations of both human and animal in their ecosystem. The term fair trade is the most common name used when emphasising on alternative commercial or business relations between producing nations and consuming nations. This system of trade has been traced as far back as 1860 when injustice was identified in coffee trade in Indonesia and Netherland (Goig, 2007). Fair trade aimed at communal and creates changes as well as consumer habits (Goig, 2007). The main objective of fair trade as outlined by Goig, (2007) include to guarantee steady source of income to employees ,to ensure the safety of work in their respective workplaces are assured or maintained, improve equality for women, protecting the right of under aged workers(child labour) or minorities as well as the environment. 
In recent times global sales for fair trade products increased more than $£ 758$ million in 2005 , and in 2002 it raised about $265 \%$ level with UK market estimated to increase up to $£ 230 \mathrm{~m}$ by the end of 2006 (Doherty and Tranchell). There have been arguments that involving retailers in the major fair trade strategy will lead to growth and sustainability (Doherty and Tranchell). However, authorities have noted that in spite of the growth of fair trade sales, a number of debates have been going on, on the relevance and vital role fair trade play in the economy. Doherty and Tranchell (2007) note that there have been marginalized producers since the advent of fair trade in civil societies. However, fair trade has particularly attracted significant interest and growth in the food and fashion sector and the sales of fair trade products have doubled over the period of 2001 to 2003(Shaw,2006). fair trade lead to positive benefits although some factors could inhibit organizations from achieving these goals.

In the food choice, the establishment of fair trade has received ample attention from labelling certification through the avenues created by fair trade foundation Mark (Shaw, 2006). In addition, European Fair Trade Labelling Organization which is made up of 315 companies constitute 500 producers and 1.5 million farmers and labours from 40 countries. Products associated with fair trade were sold in over 2700 outlets and 57 thousand supermarkets in Europe (Becchetti and Rosati 2007). These suggests that fair trade has achieved a substantial market share and growth over the years, although not in all areas.

\section{Fair Trade and Fashion}

Large number of consumers and organisations are knowledgeable about fair trade relating to fashion sector and mainly linked to sweatshop productions. Fair trade practices are mainly described through sweatshop (Shaw et al, 2006). Although there are different definitions attached to sweatshop, Shaw et al (2006) looked at it from "factory production perspective" where employees are exploited by offering them low wages with long working hours as well as engaging under aged labour force(child labour). This also extends to other exploitative practices and mainly carried out in developing countries where labour laws and the right of workers are frequently undermined. Shaw et al (2006) opine that studies that investigate decision making regarding ethical consumer practices have been unveiled, although consumers place ethical considerations very high during their purchase decision. Most times, it is mainly not at the disadvantage of other additional traditional factors relevant to choice .An example of a UK fair trade that illustrate this include the coffee Brand Cafedirect which ensured that despite providing ethical brand, it was necessary to also provide and supply good quality products already in the market which made these products successful (Shaw et al, 2006).

Studies in UK and US have revealed that consumers are in demand for more fairly traded clothing packages. This is not to the detriment of the item bought but was evident from the protests regarding fair trade which were obsolete and available to consumers. Unlike the developing nations, the role of clothing in developed nations is not associated with only the functional needs, but needs for belongingness and self esteem as stated by Maslow's hierarchy of need. This triggers individuals to indulge in fashionable clothing as a means of gaining social status (Shaw et al, 2006). This was illustrated in the sign value of successful brand. In terms of ethics, it is the responsibility of the consumers to manage their wants and need for individual uniqueness through fashion products and as well as their worriers regarding sweatshop labour. As suggested by Shaw et al (2006) there are quick change of styles, novelty and mass consumption characterised by fashion companies or firms. This makes such fashion companies 
to differ the views and ideas linked to ethical consumptions. The authors went further to assert that people have argued that there is regular state of lifestyle and dissatisfaction in terms of fashion because it is promoted from a low and materialistic standpoint.

Consumers who believed in ethical issues or in making ethical choice have power to encourage companies in order to avoid exploitations of humans. In this regard, it is believed that these consumers use their buying decision to show off their attitude, opinion and beliefs toward this, thus purchase of some products /item is linked to a vote. A number of studies(e.g see Shaw, et al, 2006) have pointed out the fact that purchase vote especially in food choice have shown that market for organic and fair trade products have grown and there are constant increase in availability of these products or items in normal markets (Shaw, et al, 2006). Despite an increase in availability of these items in mainstream markets, markets for ethical clothing are low, making individuals that want to convey their personal norms and beliefs through ethical choice indefensible. Shaw et al (2006) point out that although buyers may consider avoiding sweatshops clothing but in real life, inconsistency may arise when decision to buy those items are made. This situation often occurs in markets where there is limited information on products, or availability of such products as well as alternatives regarding choice of fair trade. Results from Shaw and Duff (2002) show that consumers were unable to act upon the information during purchase due to conflicts on the information of the products, as well as, lack of positive information. The authors concluded that it was not information regarding fair trade that was lacking rather most of them believed that this was well recognized by peers and mass media. However, there are some products that have no labels to ensure the standard of produce for fair trade, though consumers delved into clue in the event that it will hamper the labour force welfare employed in the country (Shaw et al, 2006).

According to Shaw and Duff (2002) despite result showing that consumers indulged in actions such as boycott, most of them are eager and have the chance of making ethical considerations. Although, without ruling out entirely that some retailers exist, most of them where found on that internet where they are criticized for their inability to give thoughts over fashion aspects of fair trade products. The result of such unfavourable choice made it difficult to prove the success of the buying strategies deployed by concerned consumers (shaw et al, 2006). Regardless of these difficulties, clothing has become an important element in the context of consumptions, however, non existence of ethical and information regarding fair trade hinders consumers to articulate their ethical issues by voting (shaw et al, 2006).

\section{Reaction of the market on fashion}

Studies (e.g. see Law, 2000; Weadick, 2002) suggest that fair trade clothing has not been represented fully in the marketplace. According to Watson, (2001) and Shaw et al, (2006), consumers should understand that organic purchase associated with textile regardless of the importance of fair trade products associated with food sector. Despite the introduction of organic cotton by retailers like Mark and Spenser in the UK and Missoni located in Italy, consumers regard more provisional ethical choice as a result of poor availability of alternative conventional outlet. Although most consumers consider the practice of ethical organizations, it does not mean that they will have to buy their products or avoid companies that are unethical in their business dealings. In making purchase decisions on fair trade, clothing is important because of the relevance of brand image and the status of fashion. 
Shaw et al, (2006) reveal that consumer's boycott has increased, hitting 618840. In addition, companies suffer tremendous commercial losses when consumers indulge in boycotts and because of such boycott most renowned companies like Gap and Nike have partake in practices that are unethical practices. Therefore, it is important to emphasize on boycott so that such practices can be understood by consumers and companies can know the negative impact such practices may have on their image (Shaw, et al 2006). While many consumers are in support of boycott by companies, they are also aware of their rights and ethics in business practices because of large volume of information available although wrong information may cause information overload. Consumers although wish to see groups that indulge in campaign and that media supply vital information on positive choice on alternatives (Shaw et al, 2006), consumers are more likely to involve in ethical purchase because of the level of information available which are likely to reduce pressures. Furthermore, there is always confusion arising when consumers understand the influence of boycotting child labour which often leads to under age persons being employed in dangerous jobs. This issue has been considered by UK Campaign Organization Labour (Shaw et al, 2006). The extent of such boycott has a negative influence on organizations image and damages the relationships companies have with the public and their business partners.

There are lots of consumers' choices in food where many ethical substitutes are available to many of the outlets yet there have limited ethical alternatives in fashion and more precisely in clothing especially in small markets (Shaw et al, 2006). Researchers suggests that consumers are unlikely to fully support the fashion sector due to the availability of more traditional product choice and this availability has remained vital in the context of consumption(Shaw et al, 2006).This debate according to Shaw et al, (2006) is regarded as the emergence of "ethical market on a continuum of focus" which is a gain play familiarizing the market for ethical niche which looked at the wholly or in part the encouragement of ethical record to address ethical issues within markets where ethical encouragements are less an important factor (Shaw et al, 2006).

Furthermore, some organization may not react to ethical practices at all which is likely to support the outsourcing of production, and perhaps clothing, where labour activities are questionable (Shaw et al, 2006). While failure to act by the strength of the consumers, could warrant deadly and unbefitting consequences to the organization, it is important to understand the ethical beliefs and values of consumes to both small and corporate strategies as buyers react against green products last decades was pointed out. While the benefits of small ethical scope is vital in terms of a more wide-ranging approach, to ethics, the high level of criticism to ethical organisations is a method to ensure that organisations live up to ethics by example or reputation.Ethical conventions and benefits from a wider market access though may suffer some criticisms of changes that occur in market preferences rather than normal ethical practices leading to exploitation, It is worthy to note that ethical practices are neither stable, nor fixed thus they are unpredictable. Therefore it is vital that organizations responds to ethical issues and look at the social and cooperate social responsibility, brand image, value change, which might be essential or vital in strategic decision making.

\section{Cooperate Social Responsibility and Fair Trade}

Research (e.g Hollander 2004) supports the notion that consumers respect companies that support communities where they operate than companies that neglect communities where their activities are carried out. Becenti and Rosati (2007) note that social responsible consumption 
such as fair trade go together with some ill strategies introduced by some of the retailers. Some of these strategies put up by retailers include a decision for supermarkets to embark on selling fair trade products which have helped fair trade organizations imports to help reduce distribution problems associated with limited and dedicated fair trade shops (Becchetti and Rosati 2007). However, in recent times many companies have put up advert both for prices and quality of items they sold, but social responsibility actions, social labelling and corporate responsibilities are becoming important. Corporate social responsibility (CSR) deals with moving businesses from "a single bottom-line philosophy" to motivating organisations to undertake functions that do not only involved in profit making but extends to protecting the environment and support education in the community they are operating (Davies and Crane, 2010). It Involves bringing together of environmental, social and economic issues into the business strategy and organisational method of operation. According to Commission of the European Communities (2001) it is "a concept whereby companies integrate social and environmental concerns in the business operation and in the interaction with stakeholders on a voluntary basis". CSR is all about how businesses organizes in such a way they have positive impact to the entire community. Similarly, Jones et al., (2007) point out that CRS has been widely applied in businesses as growing number of companies are committed to making and keeping the environment self as wells as attending their economic goals. This makes it possible for retailers to report on a range of issues (Jones et al., 2007). While Jones et al., (2007) points out factors that motivate the increasing participation of CRS by companies such as the social and environmental behaviour, pressures on stakeholders pressures on investors, peer ' pressures ,increase acceptance of social responsibility as well as awareness of corporate ethics, the commission of the European Communities argues that there have been increased acceptance of CSR by organizations because it helps them make changes and act in accordance to the rules and norms of the business environment they operate. Such changes range from globalisation down to the roles companies are expected to perform as they source for products and raw materials in developing countries (Jones et al., 2007). While Jones et al., (2007) opine that CSR has a lot of benefits which include improvement on profitability as a result of better financial routines, lowering operating costs, employees sustainability, motivating staff commitments, improve the capacity for innovate, better relations between the companies and governments good risk management reputation and brand image, fair trade will actually do well if organisations perform their bits in communities where their activities are carried out.

\section{Branding and fair trade}

Brand had never been linked to more valuable or vulnerable because they are exposed for the public to examine. Brand is directly linked to trust allowing consumers and trade men in this information age and buyers. Doherty and Tranchell, (2007) stress that while there are arguments as what constitutes brand, development of fair trade brands is vital for future market growth of fair trade. Edifying a strong brand has become one of the main marketing priorities for brand that help business. Scott and Hallign (2002) note that brand has been argued to trigger almost two- thirds of customer purchases and motivates nearly every purposeful area of the business. Many organisations have witnessed improvements in terms of their profit base and increased investment in development, creation, and introduction of new brands. Most organisations that are not used to branding have started recognising the importance of such marketing tools. Whether organisations are operating as retail firm, who see consumers, manufacturers or institutions, customer focus should be at the heart of their business strategies and brand positioning, image, value and management should be a major and critical part of organisational effort (Hans D. and Tom D.2008). As Hans D. and Tom D. (2008) put it, people 
have failed to realize that brand reside in the head and heart of the ultimate consumers not on the containers. Buyers or the ultimate users of fair trade e products would prefer to understand the benefits brand offers, location where they can get the brand, the cost associated with the brand before buying the brand. A paper "Connecting Energy Company Brand Position to Brand Image "delivered by Suzanne Hogan, notes that firms should position their brand because consumers are influenced by a brand position in a bid to have choice. Today brand choices are many and differentiation so trivial in terms of product functionality that we faced so many imperceptible offering. Fair trade and their branded products needs to impact on the lives of consumers in the campaign for successful fair trade in future.

\section{Fair trade and ethical consumptions}

Literature in Sociology (see Goig, 2007) has supported the notion that there are emerging models of ethical consumers Despite mass consumerism has remained the core model associated with developed nations of the world, a number of studies have discussed the birth of ethical consumers which is new. According to Goig (2007), the new ethical consumers have been quite different from those existed in the days of Fordist and neo-liberal period. The ethical consumers emerged precisely from the development of great disparities and social prohibition which emerged from the resent consumerism (Goig, 2007). The emergence of ethical consumers could also be linked to some problems of the ongoing environmental destructions, however, it is believed that ethical consumers deals with the safety of the products, production processes and their influence on the health as well as the environment (Goig, 2007). Ethical consumers also extend to the respect for human right and identity building. Apart from responsible consumers, products recycled and traded and /or sustainable development, fair trade has been linked as an alternative ways of buying and living (Goig, 2007).

According to Nicolas and Lee (2006) consumers are always motivated to make choice based on the feature of the product which has an aspect of social and environmental that must be positive. Although fair trade has emerged as an influential factor on products that are associated with ethics, the total number of sales on fair trade worldwide has amounted $£ 335$ million in 2002, the sales figure has been estimated to move up to 1 billion by in 2007(Nicolas and Lee,2006). Recently there are about 5000-7000 fair trade products which are estimated that more than 5 million people are already benefiting from it globally (Lee, 2006). However, despite the increasing number of people who are benefiting on fair trade products and the success of it over the years, Nicolas and Lee (2006) point out that there is a massive inconsistency about those people who are the core buyers of fair trade products and supports fair trade and market share of some majority of fair trade research conducted by Cowe and Williams(2002) highlights that over one third of UK buyers consider themselves as ethical buyers yet, fair trade only account for less than 1-3 of UK individual market which is specifically termed Ethical purchase gap(Nicholas and Lee,2006). Nicolas and Lee (2006) also point out that differences exist between ethical intent and actual purchase behaviour with regards to the fair trade however, a survey conducted by corporative group that reach out more than 30000 , UK buyers, find that 43 percent ensure that there are increasingly fair trade deal for producers in third world countries (Nicolas and Lee 2006).

Problems associated with ethical purchase as pointed out by Nicolas and Lee (2006) are small availability of products, limited number of multiple products available, lack of trust about fair trade claims., the level at which buyer over exaggerate their intention to buy fair trade products and lack of effective promotional tools for the producers of fair trade products. Regardless of 
these problems, researchers have pointed out that little research have been conducted which aimed to unfold the norms and attitudes of consumers regarding fair trade or the ethical issues associated with the products. Nicolas and Lee (2006) opine that where such information is not available researchers are unable to understand the reason for some of these problems thus impact negatively in solving some of the problems.

\section{The benefits of Fair Trade}

According to Ethical Purchasing Index which examines the gaps that exist between peoples view and consumers related interests about ethical issues relating to fair trade and what the spending behaviours of consumers on fair trade products are (Doherty and Tranchell, 2007), the problem of availability of fair trade products in major markets is a hindrance to fair trade brands. However, about 2500 fair trade products are said to be available in major markets in UK which entered through a number of different routes (Doherty and Tranchell, 2007). These routes include;

- $\quad$ Fair trade products from fair trade companies and all products introduced in UK markets by these companies carry marks associated with the fair trade products.

- Through some of the manufacturers branded Fair-trade products became part of the products that entered the UK with the fair trade marks on them

- Retailers also carried fair trade products with own labels. These products were recognised on the store shelves of these multiple retailers

- Mark and Spencer and Coffee companies also introduced their own brand with their own labels

- $\quad$ Retailers and other fair trade companies also worked together to produced a joint labelled fair trade products.

Doherty and Tranchell (2007) citing a proposal made by Lowe and Davenport (2005), note that fair trade has moved the massage that is associated with it, from being carried out internationally to involving individuals shopping which lay emphasis on the dimension of price for producers as well as product quality. Individual ethical consumption have been argued to lack direction although Ranson (2005) report that accessibility of these product elicit some sort of practical means that triggers almost anyone to counteract the trading justices associated with international trade or global sales. Doherty and Tranchell (2007) point out that to make a purchase of the fair trade product in grocery stores was a very understandable massage which brought a number of researchers agreeing and disagreeing with the consumer act not a merely economic agent, nor political agent but a combination of both. They stressed that as consumers are citizen that have identities, beliefs and values that is narrowed down to their needs and wants. As these consumers make purchases, it is often based on voting.

Although some arguments have been made on fair trade, organizations that are in the mainstream markets have the opportunity to reach out the wider buyers which result to increase in the sale volume as the fair trade massage spread through favourable word of mouth fair trade. However, campaign about fair trade has failed to rich to wider populations or consumers that enables commercial business tycoons to regulate their activities (Doherty and Tranchell, 2007). Such situation has made a lot of scholars to come to the conclusion that fair trade is losing is worth in the society. Although many sees fair trade as much more than certification activities, it tries as much to bring about the equality in trading relationships between groups, and countries. While equality was necessary in trading between nations, it is worthy to note that it is imperative that as business indulge in fair trade, they should consider the community in 
which they operate and provide some of these communities with the basic social amenities especially in developing countries (Doherty and Tranchell, 2007). Fair trade has been successful to some extend through the building of relationships with producers and devoting in supply chain in a bid to build competence in most of the manufacturing organisations which requires both work and competence to both development and support regarding producers (Doherty and Tranchell, 2007).

\section{Analysis and Discussion}

Empirical studies reviewed in this study show that many consumers who wish to indulge in buying ethical clothing feel that fair trade means sweatshop -free production. The analysis of such result shows that there are high barriers in buying fairly traded sweatshop clothing in a bid to ensuring that there are free nature of such clothing before taking actions on whether to buy them or not. Shaw et al, (2006) point out that one problem associated with the purchase of such ethical clothing among consumers is lack of information. Hence the perceive barrier associated with the purchase of such fair trade is linked to the problems in the market where they consider information available in the market as inadequate and thereby limiting its perceived availability and the associated significance in indicating producers of fair trade products (shaw et al,2006). These had made consumers to make claims that do not reflect any polices relating to ethics on trading off ethical intentions for fashion or the associated price.

Fair trade must be capable to deal with the ethical issues alongside quality, test and its availability, it is important to note that fair trade clothing must equally fulfil consumers' desires needs, and requirements for fashion and its availability (Shaw, et al 2006). Therefore, retailers who believe and abide by ethical trading must look into the fashion element of the products they market in order to fully make an assessment of major markets where fair trade products are being sold. More ethical issues must also be tackled by existing high street outlets who do not have problems associated with availability and try as much as possible to address some ethical issues concerning their products and labelling (Shaw, et al 2006).

Fashion organisations who intend moving into fair trade, should understand that introducing fair trade labelling would go a long way to help them and the consumers to understand the ethical issues and nature associated with such items. This will impact positively on the time consumers spend in searching for information that will help them make their purchase decision as research confirmed that introducing such labels is capable of proving successful as consumers have regularly look at labels to determine sweatshop nature of the cloths(Shaw, et al 2006).

Although this studies revealed that on ethical food market that consumers are eager to pay for ethics, price has been regularly pointed out as a barrier to ethical purchases in clothing/fashion industry even for consumers who are motivated. This suggests that organisations should incur additional cost during ethical practices to avoid keeping away buyers. According to Shaw, et al (2006), this will provide added information in terms of awareness for fair trade and ensure that people are kept informed as the purpose of fair trade is to pay a living wages to the manufacturers, thus consumers may be expected to pay more on these fair trade products.

There are increasing interests on responding to ethical issues regarding consumers by fitting in ethical issues into organisational structures and practices. As Crane, (2004) argue that ethics among retailers will be subjected into examination in today's market. Shaw et al, (2006) also note that a company like Gap has open reports into their producers and suppliers indicating this 
issue where their previous reports which are labelled negative are displayed. This company has showed element of openness to ensure that their image are not in a bad press any further. Ethics will be a matter of concerns when its affects consumers in certain issues especially when the successes of some markets are linked to consumer health issues such as the degree of organic purchasing. Therefore clothing organization that indulge in fair trade should understand that though fair trade is vital, there are certain ethical considerations that need to be considered to avoid exploitation.

Logistics and distribution also create problems because they are often subjected to a long distance from where the consumers are residing (Becchetti and Rosita, 2007). This trigged most fair trade organizations who buys these items in other countries to indulged in large scale distribution to sell their items despite their are misconception among buyers and producers in terms of their respective principles. Organizations that intend to focus on fair trade products must evaluate the distance where such products are transported. This will help reduce the neglect of these products by consumers (Becchetti and Rosati 2007).

\section{CONCLUSION}

The overall objective of this study was to explore the relevance of fair trade and argue for and/or against it in organizations, most especially, in clothing industry. Fair trade is a two edge sword which has its benefits as well as its drawbacks. Wright and Heaton (2006) for example note that despite the role of fair trade, there are concerns regarding getting more consumers to embrace fair trade products. Therefore, organizations need to take into account many factors before delving into fair trade. They need to understand that if consumers do not support products associated to fair trade, it will be difficult for them to succeed under fair trade arrangements.

Consumer's needs, desires and wants are essential because without them companies will not sales (Wright and Heaton, 2006). Though empirical investigations with past researchers point out that consumers are not aware and do not have good idea about fair trade due to poor communication which lowers the visibility and loyalty at the point where these products are sold (Wright and Heaton2006). According to Shaw et al (2006) consumers were concerned in buying fair trade products because of lack of information about such products. Thus, dissemination of information is vital to enable consumers understand the ethical issues regarding fair trade products because consumers always make their own judgement based on their own criteria that is not in line with the ethical polices and principles.

In as much as fair trade products must satisfy specified quality, taste coupled with the time and availability of the product, it is important that organization embark on fair trade in the area of clothing to fulfil consumers' desires, and preferences for fashion. According to Shaw et al,(2006) another major point which organisations must consider before moving into fair trade products is that of regulated fair trade labelling. This is vital in the sense that it will help consumers to easily reinforce the ethical nature of the products they want to buy. This will also help them to reduce the amount of time they put into searching for relevant information for such products. Also many consumers who wish to buy fair trade products have started looking for such information, however, the information on the label should be capable of proving success especially in the area of clothing. 
Paying a living wage is also essential to workers. Companies wanting to try fair trade practices should also bear in mind that living wage is necessary to workers and that child labour is detrimental to the success of fair trade. Therefore, creating awareness is vital and should be the core of fair trade. Therefore why I consider fair trade important and a means to gain credibility and improve organisational image, it is also important that these issues raised above should be taken into consideration if any company that wish to indulge in fair trade. I also recommend that companies should abide to certain ethical principles and polices in that it will help them overcome some of the problems associated with fair trade since consumer according to (shaw et al,2006) are calling for ethical products to be made available in the high streets.

Base on the above discussion and conclusion, managers of clothing organization that want to embark on fair trade practices should consider the following before delving into fair trade practice. They include:

1. Use certified label that would made explicitly clear all the formation consumers need to know regarding such products.

2. Imbibe the spirit of ethical principles in all their dealing. With ethical practices consumers will come to trust the company the more. This will boost the brand image and the associated goodwill of the company.

3. Avoid the issue of child labour. This is a vital concern in most of the recent articles.

4. Adequate strategies are important to help reach out a wider consumers regarding the fair trade products.

5. Companies must also understand that corporate social responsibility is vital in the communities where their business operates.

6. Quality has been emphases as one of the element that trigger consumers into making purchase decision therefore should be considered when indulging into fair trade.

\section{REFERENCES}

Ajzen I and Fishbein M (1980) Understanding Attitudes and predicting social behaviour, Englewood Cliffs, Prentice Hill

Anita R. (1994) Not Free trade but fair trade. Across the Board, 31(6) p58

Barrientos S. (2008) Contract labour: The Achilles heel of corporate codes in commercial value chains. Development and Change 39 (6) 977-990

Becchetti L. and Rosati F. C (2007) Global social preference and the demand for socially responsible products: Empirical evidence from a pilot study on fair trade consumers. The world Economy, pp 807-836.

Blomqvist K. H. and Posner S.(2004) The strategies for integrating CSR with brand marketing. Market Leader, p. 33-36

Commission of the European Communities (2001) Promoting a European framework for corporate social responsibility, available (online) at; http:// europa.eu.int/comm.?employment_social/soc-dial/csr/csr2002_en.pdf

Coors A. C. And Winegarden W. (2005) Corporate Social Responsibility-or good advertising. Available (on line) at www.cato.org/pubs/regulation/rev28nl/v28ni-noted.pdf(accessed 20/03/2010)

Cowe R. and Williams S. (2000) who are the ethical consumers? Manchester: Cooperative Bank/Mori 
Published by European Centre for Research Training and Development UK (www.eajournals.org)

Davies L. A. and Crane A. (2010) Corporate social responsibility in small and medium size enterprises: investigating employee engagement in fair trade companies. Business Ethics: European review 19(2), pp 126-139

Doherty B. and Tranchell S. (2007) Radical mainstreaming of fair trade: the case of the day chocolate Company. Equal Opportunities International, 22 (7) pp693-711

Fair Trade Foundation(2006) Fair trade foundation annual review, london

Goig R. L(2007)Fair trade and global cognitive orientation: a focus on Spanish fair trade consumers. International Journal of consumer studies.31, pp 468-477.

Hans O. and Tom D. 2008, Integrating Marketing Communication, European Edition, McGraw-Bill Education, Berkshire

Jones S. P., Comfort D., and Hillier D.(2007) What's in store? Retail marketing and corporate social responsibility, 25(1)17-30

Jones T.(1991) Ethical decision making by individual in organisation: an issue -contingent model. Academic of Management Review 16(2) 366-395.

Law C.(2000) The poisoned legacy of the cotton t-shirt. The Times London 26 April p.26

Nadia M.(2007) Fair trade Fashion. Time, Style 7 design 169, p42-44

Nicholas A. and Lee N., (2006) Purchase Decision -making in fair trade and the ethical purchase gap: is there a fair trade twix. Journal of Strategic Marketing (14) 369-386

Obermiller C., Burke C., Talbott E., and Green G.P (2009) Taste great or more fulfilling: the effect of brand responsibility advertising for fair trade coffee. Corporate reputation review, 12(2) pp159-176.

Ransom D. (2005) Fair trade for sale, new internationalist

Rest J. (1986) Moral development: advances in research and theory. New York

Shaw and D S. and Duff R.(2002) Ethics and social responsibility in fashion and clothing choice. European Marketing Academy Conference, Portugal

Shaw D.,Hogg G.,Wilson E.,SHIU E., and Hassan L(2006) Fashion Victim: the impact of fair trade concerns on clothing choice. Journal of Strategic Marketing, 14, 427-440

Strong C.(1996) Features contributing to the growth of ethical consumerism-a preliminary investigation. Marketing Intelligence and planning 14(5), 5-13

Nijssen E. J and D ouglas S.(2008) Consumer World-mindedess social -mindedness and store image . Journal of international Marketing, 16(3)pp84-107.

Scot D. and Halligan .C 2002, Extending your brand by optimizing your customer relationship, Journal of Consumer Marketing, Volume 19, Number 1 pp 7

Shaw D., Hogg E. Wilson E. Shui e., and Hassan L (2006) Fashoion victim: the impact of fair trade concerns on clothing choice. Journal of Strategic marketing 14, 427-440

Suzanne Hogan 2007, Positioning a Brand in the Market Place. (Online), Available: http://www.lippincott.com/insights/articles 2/a- hogon 01 (20/03/2010)

Suzanne Hogan, Connecting Energy Company Brand Position to Brand Image Available: http://www.lippincottmercer.com/insights/articles.shtml( accessed 20/04/2010)

Weadick L.(2002) Sweating it out. Ethical consumer Magazine 76,12-15 